\title{
INFLUENCE OF THE CARBONATE-FREE CLAY CALCINATION TEMPERATURE AND CURING CONDITIONS ON THE PROPERTIES OF ALKALI-ACTIVATED MORTAR
}

\author{
Girts Bumanis $^{1}$, Diana Bajare ${ }^{2}$, Aleksandrs Korjakins ${ }^{3}$ \\ ${ }^{1,2,3}$ Riga Technical University, Institute of Materials and Structures, Chair of Building Materials and Products, \\ Kalku Str. 1, LV-1658, Riga, Latvia
}

E-mail:" girts.bumanis@rtu.lv (correspondingauthor); ${ }^{2}$ diana.bajare@rtu.lv; 3 aleks@latnet.lv

\begin{abstract}
Alkali-activated materials (AAMs) are one of the most perspective alternatives to the traditional Portland cement based materials. AAMs could reduce the environmental pollution and greenhouse gas emission due to the lower heat consumption in production (up to $80 \%$ compared to the ordinary Portland cement). In the current research alkaliactivated mortar was developed from the locally available low-carbonate Illite clay. Experimental work consisted of Illite clay calcination at different temperatures and regimes (from $500-800^{\circ} \mathrm{C}$ ) and incorporation of the obtained material into the mixture of alkali-activated mortar. Four curing regimes were applied to alkali-activated mortar. The results indicate that hardened mortar properties are mainly affected by curing temperature and regime and the compressive strength up to 28.8MPa could be achieved for the mortar samples aged 2 months.
\end{abstract}

Keywords: Alkali activated mortar, curing conditions, Illite clay, calcination temperature

\section{Introduction}

Today the cement and concrete industry has become a large scale industry due to the significant consumption of cement. The total cement production in the world reached 3.7 million tons in 2012 (U.S. Geology Surway, 2013). Concrete is the second most widely used commodity in the world, after water (Aitcin, 2000). By producing such amount of cementitious materials, serious environmental pollution has been caused. Cement production contributes at least $5-8 \%$ of the global carbon dioxide emissions (Screvener and Kirkpatrick, 2008).

Ordinary Portland cement (OPC) is usually produced by heating the mixture of raw materials in a rotary kiln to about $1,450^{\circ} \mathrm{C}$ (Damtoft et al.). (Damtoft et al, 2008) have calculated that $0.53 \mathrm{t}$ of $\mathrm{CO}_{2}$ per ton of clinker is released along with an average of $0.34 \mathrm{t} \mathrm{CO}_{2}$ per ton of cement associated with the energy consumption in the production process. Alkali activated materials (AMMs) are believed to be the most promising substitute material for OPC due to the much lower $\mathrm{CO}_{2}$ emissions compared to OPC. The low $\mathrm{CO}_{2}$ emission level is reached by using lower temperature for forming AAMs compared to the high sintering temperature used in OPC production. Calculation of $\mathrm{CO}_{2}$ emissions using various alkaliactivated fly ash and metakaolin binders has been done by Duxson et al. (Duxson et al., 2007). Calculation included $\mathrm{CO}_{2}$ emissions during production of $\mathrm{Na}_{2} \mathrm{O}$ in the chloric-alkali process; $\mathrm{SiO}_{2}$ as aqueous sodium silicate was used as the primary inputs and the calculation showed that $\mathrm{CO}_{2}$ saving was up to $80 \%$ compared to $\mathrm{CO}_{2}$ emissions in OPC production .

Alkali activation of the materials containing amorphous $\mathrm{Al}_{2} \mathrm{O}_{3}$ and $\mathrm{SiO}_{2}$ is a way in which specific cementitious materials are produced. Alkaline activation of raw material composition with the concentrated $\mathrm{NaOH}$ solutions produced an amorphous material - a zeolitic precursor with excellent cementing properties in terms of mechanical strength (Palomo, 1999). The rate of chemical reactions was influenced by various parameters such as curing temperature, alkali concentration, initial solids content, etc. When the activator concentration increased, a delay in material structure formation was observed, whereas the increasing temperature accelerated its formation.

In the present research low calcium alkali activated binder has been developed. The fundamental binder structure in low-calcium alkali-activated systems is known to be a highly disordered, highly cross-linked aluminosilicate gel. Both $\mathrm{Si}$ and $\mathrm{Al}$ are present (Duxson et al., 2007). Alkali hydroxides are usually combined with an aluminosilicate source in the form of an aqueous solution (Provis, 2009). Given the complexity of the gel structure, which is formed through silicate activation of fly ash or metakaolin, and in particular its dependence on a large number of compositional and processing parameters, various approaches to the analysis of the gel binder were developed and implemented in the past years (Rahier et al., 1997, Palomo et al., 2005, Yao et al., 2009,).

Researches have shown that kaolinite clay is not the only natural source material to form alkali-activated systems. Illite-smectite clays have also shown strong potential for utilization in alkaline activation applications and the high Si content of the clays favours the use of a low-silicate alkaline activation solution in these systems (Buchwald et al., 2009). Other researches have shown that AAMs could be obtained from different types of grass ashes and waste materials together with calcined Illite clay at elevated curing temperatures and compression strength results could be up to $23 \mathrm{MPa}$ (Bajare et al. 2011).

In this research carbonate-free Illite clay will be investigated in order to obtain alkali-activated mortar. The effect of calcination temperature of clay minerals will be tested and optimal curing conditions of forming AAM will be obtained. 


\section{Experimental setup}

The basic raw materials used in the current study in order to obtain alkali-activated mortar were carbonatefree Illite clay (IC), lead silicate glass waste (LSG), sand, $\mathrm{NaOH}$ flakes and water. Alkali - activation of raw material composition was done by $6 \mathrm{M}$ sodium hydroxide solution. Materials were processed before application in the AAM.

\section{Materials}

\section{Carbonate-free Illite clay}

Carbonate-free Illite clay (IC) was used as a source of aluminium and silica dioxides needed in the activation process. Chemical composition of IC is given in Table 1.

Table 1. Chemical composition of Illite clay, lead-silicate glass and sand (w\%).

\begin{tabular}{|c|c|c|c|}
\hline & Illite clay & LSG & Sand \\
\hline $\mathrm{Al}_{2} \mathrm{O}_{3}$ & 15.5 & 1.0 & 15.1 \\
\hline $\mathrm{SiO}_{2}$ & 62.2 & 69.1 & 76.5 \\
\hline $\mathrm{CaO}$ & 0.8 & 1.3 & 1.2 \\
\hline $\mathrm{SO}_{3}$ & - & - & 0.1 \\
\hline $\mathrm{TiO}_{2}$ & 1.9 & - & - \\
\hline $\mathrm{Na}_{2} \mathrm{O}$ & 0.1 & 8.0 & - \\
\hline $\mathrm{K}_{2} \mathrm{O}$ & 4.1 & 1.2 & - \\
\hline $\mathrm{MgO}$ & 1.3 & - & 0.4 \\
\hline $\mathrm{Fe} 2 \mathrm{O}_{3}$ & 7.2 & 0.2 & 0.6 \\
\hline $\mathrm{PbO}$ & - & 19.0 & - \\
\hline $\mathrm{LOI}, 1000^{\circ} \mathrm{C}$ & 4.7 & - & 5.9 \\
\hline $\mathrm{Total}$ & 97.8 & 99.8 & 99.8 \\
\hline
\end{tabular}

IC was calcined in four temperature regimes - from 500 to $800^{\circ} \mathrm{C}-$ by using slow and rapid calcination methods. The slow calcination regime was the following: - heating rate was $10^{\circ} \mathrm{C} / \mathrm{min}$ and $\mathrm{IC}$ was kept at the maximum temperature for $3 \mathrm{~h}$. Rapid calcination regime was applied by using laboratory rotary furnace for sample $700^{\circ}(\mathrm{R})$. Sample $700^{\circ}$ (R) was calcined for 15 minutes at the maximum temperature $\left(700^{\circ} \mathrm{C}\right)$. The specific test methodology was created at the Institute of Silicate Materials, Riga Technical University, to detect reactivity of calcined clays used in the AAM. The amounts of amorphous $\mathrm{SiO}_{2}$ and $\mathrm{R}_{2} \mathrm{O}_{3}$ in the calcined IC are given in Table 2 .

Table 2. Amount of amorphous $\mathrm{SiO}_{2}$ and $\mathrm{R}_{2} \mathrm{O}_{3}$ in carbonate-free Illite clay calcined at different temperatures and regimes, (w\%).

\begin{tabular}{|c|c|c|c|c|c|}
\cline { 2 - 6 } \multicolumn{1}{c|}{} & \multicolumn{5}{c|}{ Calcination temperature, ${ }^{\circ} \mathrm{C}$} \\
\hline & $500^{\circ}$ & $600^{\circ}$ & $700^{\circ}$ & $\begin{array}{c}700^{\circ} \\
(\mathrm{R})\end{array}$ & $800^{\circ}$ \\
\hline Total $\mathrm{SiO}_{2}$ & 72,70 & 72,65 & 73,15 & 72,94 & 73,20 \\
\hline $\begin{array}{c}\mathrm{Total}_{2} \mathrm{O}_{3} \\
\left(\mathrm{Al}_{2} \mathrm{O}_{3}+\mathrm{Fe}_{2} \mathrm{O}_{3}+\mathrm{Ti}\right. \\
\left.\mathrm{O}_{2}\right)_{2} \mathrm{Fe}_{2} \mathrm{O}_{3}-6,15 \\
\mathrm{TiO}_{2}-1,21\end{array}$ & 19,00 & 19,40 & 19,08 & 19,35 & 19,48 \\
\hline $\mathrm{SiO}_{2}$ active & 1,10 & 1,05 & 0,89 & 1,05 & 1,11 \\
\hline $\begin{array}{c}\mathrm{R}_{2} \mathrm{O}_{3} \text { active } \\
\mathrm{Fe}_{2} \mathrm{O}_{3}-1,16 \div 1,23 \\
\mathrm{TiO}_{2}-0\end{array}$ & 5,42 & 7,14 & 7,92 & 7,79 & 6,75 \\
\hline
\end{tabular}

The highest amount of active $\mathrm{R}_{2} \mathrm{O}_{3}+\mathrm{SiO}_{2}(8.81 \%)$ was detected for IC calcined at temperature $700^{\circ} \mathrm{C}$, but the lowest result was for IC calcined at $500^{\circ} \mathrm{C}$ $(6.52 \%)$. The rapid calcination of IC at temperature $700^{\circ} \mathrm{C}$ provided the total $\mathrm{R}_{2} \mathrm{O}_{3}+\mathrm{SiO}_{2}$ of $8.84 \%$, which was similar to slow calcination at the same temperature. It means that the maximal calcination temperature is in the range from 500 to $800^{\circ} \mathrm{C}$ and the speed of calcination does not influence the formation of active $\mathrm{R}_{2} \mathrm{O}_{3}+\mathrm{SiO}_{2}$ significantly. Compared to kaolinite clays calcined at the same temperatures $\left(700-800^{\circ} \mathrm{C}\right)$, the active $\mathrm{R}_{2} \mathrm{O}_{3}+\mathrm{SiO}_{2}$ was $33-34 \%$ (according to data from the Institute of Silicate Materials). The calcined IC was ground in a planetary ball mill Retsch PM400 for 30min with 300rpm. The specific surface of the obtained IC was in the range from 20.12 to $21.42 \mathrm{~m}^{2} / \mathrm{g}$. The micrograph of $700^{\circ} \mathrm{C}$ calcined IC is given in Fig. 1. Small particles with size from $0.5-1 \mu \mathrm{m}$ were observed on larger particles with the size up to $10 \mu \mathrm{m}$.

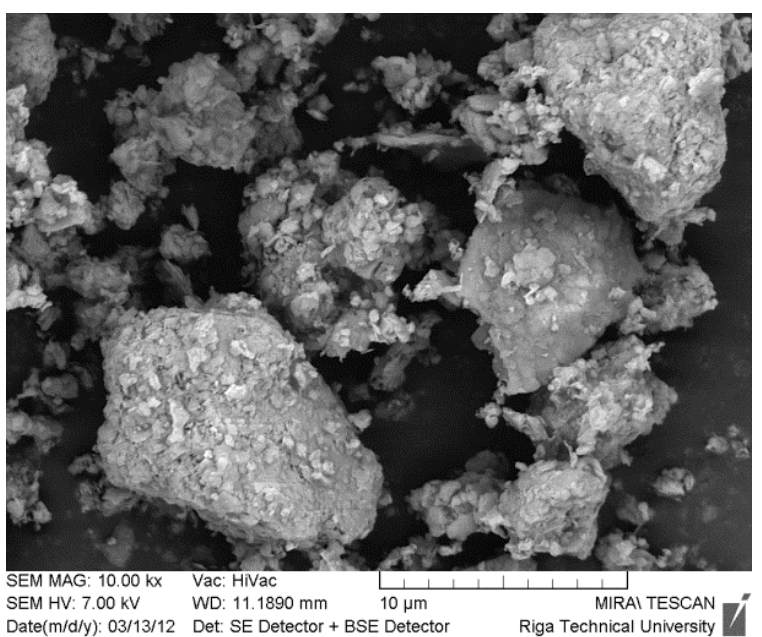

Fig. 1. $700^{\circ} \mathrm{C}$ calcined IC particle size and shape (ground in the planetary ball mill for $30 \mathrm{~min}$.).

The XRD analysis of calcined IC at $700^{\circ} \mathrm{C}$ is given in Fig. 2. The main minerals were quartz $\mathrm{SiO}_{2}$, microcline $\mathrm{KAlSiO}_{2}$ and Illite $\mathrm{K}(\mathrm{Al}, \mathrm{Fe})_{2} \mathrm{AlSi}_{3} \mathrm{O}_{10}(\mathrm{OH})_{2} \mathrm{H}_{2} \mathrm{O}$.

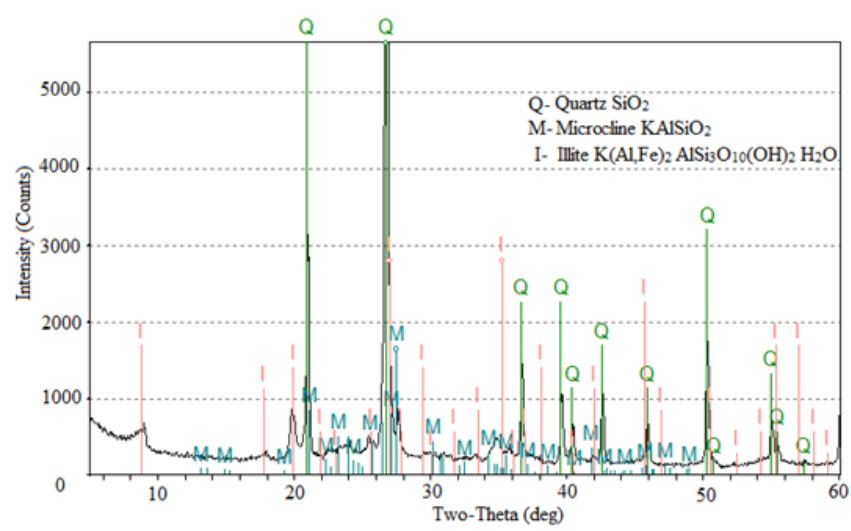

Fig. 2. XRD analysis of IC calcined at $700^{\circ} \mathrm{C}$.

\section{Lead-silicate glass waste ( $L S G$ )}

Lead-silicate glass waste used in this study comes from an outworn fluorescence lamp recycling plant. As it is not possible to recycle utilized glass by traditional methods due to specific chemical composition and high amount of lead, it poses a serious disposal problem, because glass is 
not biodegradable and land filling is not an environmentally friendly solution. Usage of this type of glass waste in the production of AAMs is a waste management solution.

Fluorescent lamp recycling process includes lamp classification, glass separation, cleaning from harmful components and glass grinding. The chemical composition of waste glass LSG is given in Table 1 .

In order to increase the fineness of waste glass, it was additionally ground in the laboratory planetary ball mill Retsch PM 400. The applied grinding period was 30 minutes. The particle size distribution in the powder material was determined by laser diffraction method. The results showed that the additionally ground material contains a wide range of particle sizes: from $8 \mu \mathrm{m}$ to $30 \mu \mathrm{m}$ with the average grain size of $26.3 \mu \mathrm{m}$. The specific surface of $30 \mathrm{~min}$ ground LSG was $0.63 \mathrm{~m}^{2} / \mathrm{g}$.

\section{Alkali activator solution}

Commercially available sodium hydroxide flakes with $97 \%$ purity were also used. The alkali-activated mortar was prepared using $6 \mathrm{M} \mathrm{NaOH}$ solution. The solution/solid (IC+LSG) mass ratio for all mixtures was constant -0.49 .

\section{Mixture design and test methods}

The main goal of research was to determinate the appropriate calcination temperature for IC to reach highest mechanical properties of alkali-activated mortar. Four different IC calcination temperatures (500, 600, 700 and $800^{\circ} \mathrm{C}$ ) and two regimes (rapid and slow) were used for calcination of IC. The mixture composition consisted from calcined IC, LSG, fine sand with fraction $0.3 / 2.5 \mathrm{~mm}$ and alkali activator solution. The mass ratio of components is presented in the Table 3.

Table 3. Alkali-activated mortar mixture composition.

\begin{tabular}{|l|c|}
\hline Component & Mass ratio \\
\hline Calcined Illite Clay & 1.0 \\
\hline Ground lead-silicate glass waste & 3.0 \\
\hline Fine sand $0.3 / 2.5 \mathrm{~mm}$ & 4.3 \\
\hline Alkali activator solution, $6 \mathrm{M} \mathrm{NaOH}$ & 2.0 \\
\hline
\end{tabular}

All dry components were mixed together for 2 minutes using electrical one shaft hand mixer. Then $6 \mathrm{M} \mathrm{NaOH}$ alkali solution was added to the mixture and mixing continued until homogenous mixture was prepared. The properties, such as consistence of fresh mortar (by flow table) according to LVS EN 1015-3 and fresh mortar density (LVS EN 12350-6), were determined. Alkaliactivated mortar mixture was cast in 40x40x160mm prismatic moulds. Moulds were sealed with plastic sheet to avoid rapid water evaporation before specific curing regime was applied.

Four curing conditions were chosen: temperature regime of $75^{\circ} \mathrm{C}$ for $24 \mathrm{~h}$ and $72 \mathrm{~h}$ and of $100^{\circ} \mathrm{C}$ for $24 \mathrm{~h}$ and $72 \mathrm{~h}$. After the curing period samples were cooled at room temperature and demoulded. The samples were kept in ambient environment until testing on the $4^{\text {th }}$ and $60^{\text {th }}$ day.
Flexural and compressive strength of the hardened alkali-activated mortar bars were tested according to LVS EN 1015-11 at the age of 4 days and 60 days.

\section{Results}

Fresh alkali-activated mortar results indicated that IC calcination temperature does not affect fresh mortar density (it was in the range from $2005-2025 \mathrm{~kg} / \mathrm{m}^{3}$ ) (Table 4). In the fresh mortar the lowest consistency was for mixture composition with IC calcined at $500^{\circ} \mathrm{C}-$ $157 \mathrm{~mm}$. For other mixtures fresh mortar consistency was in the range from 180-198 mm.

Table 4. Fresh alkali-activated mortar properties.

\begin{tabular}{|c|c|c|}
\hline $\begin{array}{c}\text { IC calcination } \\
\text { temperature and } \\
\text { regime, }{ }^{\circ} \mathrm{C}\end{array}$ & $\begin{array}{c}\text { Fresh mortar } \\
\text { density, } \mathrm{kg} / \mathrm{m}^{3}\end{array}$ & $\begin{array}{c}\text { Consistency } \\
\text { (flow table) } \mathrm{mm}\end{array}$ \\
\hline $500^{\circ}$ & 2010 & 157 \\
\hline $600^{\circ}$ & 2011 & 181 \\
\hline $700^{\circ}$ & 2009 & 195 \\
\hline $700^{\circ}(\mathrm{R})$ & 2005 & 180 \\
\hline 800 & 2025 & 198 \\
\hline
\end{tabular}

The flexural strength of the hardened alkali-activated mortars is given in Figure 3. The lowest flexural strength was for samples cured at temperature regime $75^{\circ} \mathrm{C}$ for 24h. It was in the range from 1.5-2.0 MPa. By extending the curing period from $24 \mathrm{~h}$ to $72 \mathrm{~h}$ at temperature $75^{\circ} \mathrm{C}$ flexural strength of all specimens increased almost twice and reached 2.6-5.5 MPa. The highest flexural strength was reached in the specimen with IC calcined at temperature $800^{\circ} \mathrm{C}-5.5 \mathrm{MPa}$ followed by $700^{\circ} \mathrm{C}-4.5 \mathrm{MPa}$.

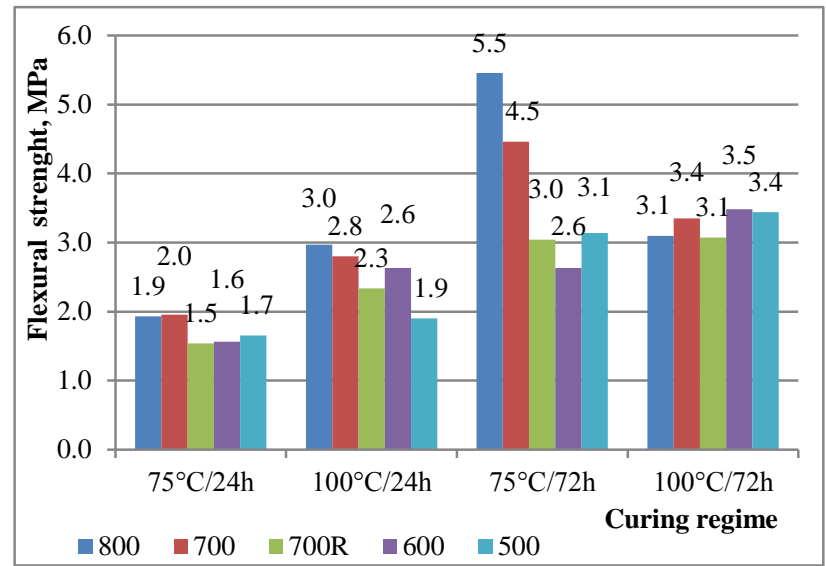

Fig. 3. Flexural strength of the hardened alkali-activated mortar samples at the age of 4days cured under different temperature regimes.

Samples cured at $100^{\circ} \mathrm{C}$ temperature for $24 \mathrm{~h}$ provided flexural strength from 1.9 to $3.0 \mathrm{MPa}$. It was approximately $1 \mathrm{MPa}$ higher in comparison with the samples cured at $75^{\circ} \mathrm{C}$ for $24 \mathrm{~h}$. The samples cured for $72 \mathrm{~h}$ at $100^{\circ} \mathrm{C}$ provided flexural strength from 3.1 to 3.5 MPa. The strength increase could be described with prolonged cementitious mineral formation. Comparing with the results at temperature regime $75^{\circ} \mathrm{C}$ for $72 \mathrm{~h}$, the strength was lower but it was distributed more evenly between mixtures. 
Results of compressive strength for 4 day old alkaliactivated mortar samples are given in Figure 4. The compressive strength of all 4 days old specimens did not depend on the curing temperature $\left(75^{\circ} \mathrm{C}\right.$ or $\left.100^{\circ} \mathrm{C}, 24 \mathrm{~h}\right)$ and were between 5 and $8 \mathrm{MPa}$. With longer curing period of $72 \mathrm{~h}$ at the temperatures $75^{\circ} \mathrm{C}$ and $100^{\circ} \mathrm{C}$ the compressive strength of all 4 days old specimens increased significantly - two to three times. The average compressive strength of specimens cured at elevated temperatures $\left(75\right.$ and $100^{\circ} \mathrm{C}$ ) for $72 \mathrm{~h}$ was between 12 and $19 \mathrm{MPa}$. The highest result was reached for the mixture with IC calcined at temperature $800^{\circ} \mathrm{C}$ and cured $72 \mathrm{~h}$ at maximum temperature $75^{\circ} \mathrm{C}(18.7 \mathrm{MPa})$.

Samples cured at the higher temperature $\left(100^{\circ} \mathrm{C}\right)$ showed strength increase by $20-50 \%$ compared to the samples cured at $75^{\circ} \mathrm{C}$.

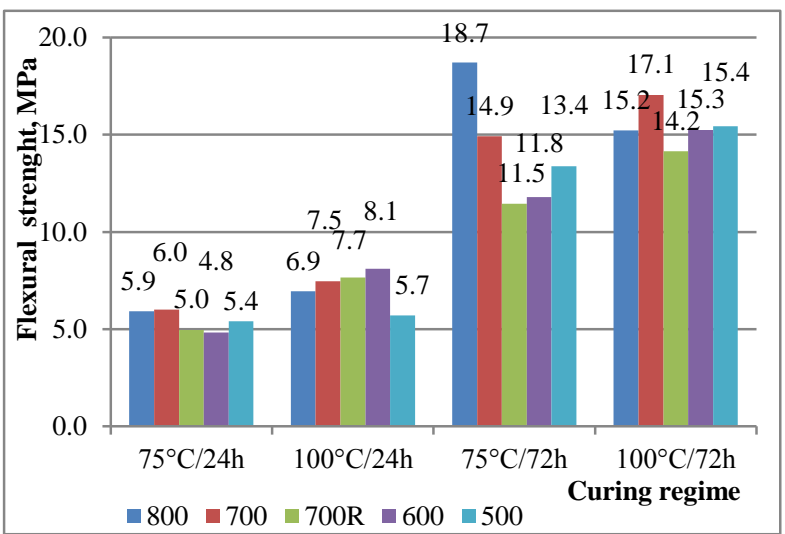

Fig. 4. Compressive strength of the hardened alkali-activated mortar samples hardened at the age of 4 days.

According to these results it was possible to conclude that the period of curing at elevated temperature is the main factor influencing increase of early age compressive and flexural strength for alkali activated mortars made from IC.

The long term compressive strength has provided significant strength increase for all mixtures and curing conditions (Fig. 5). At the age of 60 days samples cured at $75^{\circ} \mathrm{C}$ for $24 \mathrm{~h}$ demonstrated compressive strength from 8.2 to11.6 $\mathrm{MPa}$. Highest result was shown by the samples with IC calcined at temperature $700^{\circ} \mathrm{C}(11.6 \mathrm{MPa})$. The strength increase of 60 days old samples was between 70 $90 \%$ compared to the samples cured at the same regime but tested on the $4^{\text {th }}$ day.

The compressive strength for samples hardened for $72 \mathrm{~h}$ at $75^{\circ} \mathrm{C}$ was from 18.8 to $28.8 \mathrm{MPa}$. The highest result was for the mixture composition with IC calcined at temperature $800^{\circ} \mathrm{C}(28.8 \mathrm{MPa})$. Compressive strength increase was from 60 to $80 \%$ compared to the $4^{\text {th }}$ day strength results. Summarizing the test results, it can be observed that samples continued to gain strength significantly over time with no relation to the time period of curing ( 24 or $72 \mathrm{~h}$ ), but the tendency was that the prolonged curing period $(72 \mathrm{~h})$ led to higher strength even on the $60^{\text {th }}$ day of testing.

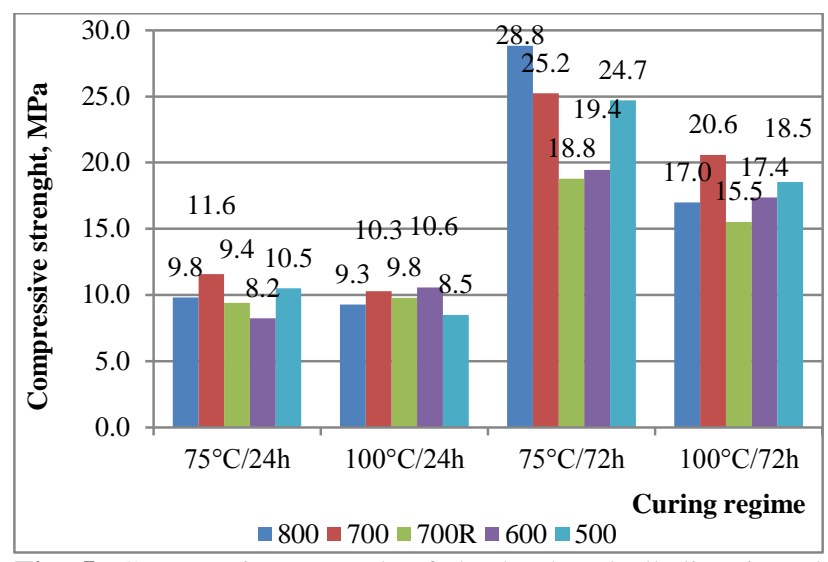

Fig. 5. Compressive strength of the hardened alkali-activated mortar samples hardened at the age of 60 days.

Samples cured at $100^{\circ} \mathrm{C}$ have demonstrated lower strength increase compared to the samples cured at $75^{\circ} \mathrm{C}-28-49 \%$. Testing on the $60^{\text {th }}$ day shows strength from 8.5 to $10.6 \mathrm{MPa}$ for mixtures hardened for $24 \mathrm{~h}$. If compared to samples cured at $75^{\circ} \mathrm{C}$ for the same period of time, the compressive strength results were more stable for all mixtures. Samples cured at $100^{\circ} \mathrm{C}$ were with lower strength increase compared to samples cured at $75^{\circ} \mathrm{C}$. The reaction processes were enhanced during primary curing, therefore further strength increase was with lower increase rate.

Samples hardened at $100^{\circ} \mathrm{C}$ for $72 \mathrm{~h}$ at the age of 60 days show insignificant strength increase - from 16 to $20 \mathrm{MPa}$. Strength increase was from 10 to $20 \%$ comparing to 4 day test results. The average results for samples cured at $100^{\circ} \mathrm{C}$ were lower compared to the samples cured at $75^{\circ} \mathrm{C}$ for all mixtures, but these results were much more stable.

\section{Conclusions}

Alkali-activated mortar could be created using carbonate-free IC calcined at different temperatures between $500-800^{\circ} \mathrm{C}$. Amount of amorphous $\mathrm{R}_{2} \mathrm{O}_{3}$ in the calcined clay does not have direct correlation with the strength results of the obtained alkali activated mortar. The mechanism of alkali activation must be investigated properly in the future. The highest strength results for alkali-activated mortar were obtained with IC calcined at $800^{\circ} \mathrm{C}$ with amount of amorphous $\mathrm{R}_{2} \mathrm{O}_{3}+\mathrm{SiO}_{2} 7.86 \%-$ $18.7 \mathrm{MPa}$ at 4 days and $28.8 \mathrm{MPa}$ at 60 days.

Curing conditions are an important issue for creating AAMs. By choosing appropriate curing conditions and regime cementiteous material with similar properties to cement based materials could be created. The optimal curing temperature could be in the range from 70 to $80^{\circ} \mathrm{C}$. By increasing temperature from 75 to $100^{\circ} \mathrm{C}$ small compressive strength increase was observed. The initial strength of alkali-activated mortar increases and results are distributed much more evenly between mixture compositions compared to the results obtained from samples cured at $75^{\circ} \mathrm{C}$.

The prolonged curing period leads to strength increase at both temperature regimes. The 4 day strength could be 
increased by $100-200 \%$ just by increasing curing period from $24 \mathrm{~h}$ to $72 \mathrm{~h}$.

Alkali-activated mortars continue to gain strength during time. All samples demonstrated strength increase between $4^{\text {th }}$ and $60^{\text {th }}$ day. The highest strength increase was for samples hardened at $75^{\circ} \mathrm{C}$ for $24 \mathrm{~h}-70-90 \%$ and for samples cured at $75^{\circ} \mathrm{C}$ for $72 \mathrm{~h}$ it was from 60 to $80 \%$. By increasing curing temperature and time hardening acceleration was observed, but further strength increase decreases with time.

The initial temperature increase rate and final cooling rate should be controlled and tested in order to avoid thermal shock for the material and to avoid thermal cracks in the structure of the material. Best compressive strength result was achieved using IC calcined at temperature $800^{\circ} \mathrm{C}$ and curing conditions were $75^{\circ} \mathrm{C}$ for $72 \mathrm{~h}-28.8 \mathrm{MPa}$ at the age of 60 days.

The obtained material could be compared to the traditional cement-lime mortars considering test results for density and mechanical and physical properties.

\section{References}

Aitcin, P. C., 2000. Cements of yesterday and today: Concrete of tomorrow. Cement and Concrete Research, 30(9), pp. 1349-1359.

Alonso, S.; Palomo, A., 2001. Alkaline activation of metakaolin and calcium hydroxide mixtures: influence of temperature, activator concentration and solids ratio. Materials Letters, 47 , pp. 55-62. http://dx.doi.org/10.1016/S0167-577X(00)00212-3

Bajare, D.; Bumanis, G.; Shakhmenko, G.; Justs, J., 2011. Obtaining Composition of Geopolymers from Local Industrial Wastes. Civil Engineering '11 - $3^{\text {rd }}$ International Scientific Conference, Proceedings, 3, pp. 50-56.

Buchwald, A.; Hohmann, M.; Posern, K.; Brendler, E., 2009. The suitability of thermally activated illite/smectite clay as raw material for geopolymer binders. Applied Clay Science, 46(3), pp. 300-304.

http://dx.doi.org/10.1016/j.clay.2009.08.026

Damtoft, J. S.; Lukasik, J.; Herfort, D.; Sorrentino, D.; Gartner, E. M., 2008. Sustainable development and climate change initiatives. Cement and Concrete Research, 38(2), pp. 115-127.

http://dx.doi.org/10.1016/j.cemconres.2007.09.008
Duxson, P.; Provis, J. L.; Lukey, G. C.; van Deventer, J. S. J., 2007. The role of inorganic polymer technology in the development of "green concrete". Cement and Concrete Research, 37(12), pp. 1590-1597. http://dx.doi.org/10.1016/j.cemconres.2007.08.018

Duxson, P.; Fernandez-Jimenez, A.; Provis, J. L.; Lukey, G. C.; Palomo, A.; van Deventer, J. S. J., 2007. Geopolymer technology: the current state of the art. Journal of Materials and Science, 42, pp. 2917-2933. http://dx.doi.org/10.1007/s10853-006-0637-z

Palomo, A.; $\quad$ Banfill, P. F. G.; $\quad$ Fernández-Jiménez, A.; Swift, D. S., 2005. Properties of alkali-activated fly ashes determined from rheological measurements. Advances in Cement Research, 17(5), pp. 155-163.

Palomo, A.; Blanco-Varela, M. T.; Granizo, M. L.; Puertas, F.; Vazquez T.; Grutzeck, M. W., 1999. Chemical stability of cementitious materials based on metakaolin. Cement and Concrete Research, 29, pp. 997-1004. http://dx.doi.org/10.1016/S0008-8846(99)00074-5

Provis, John, L.; van Deventer, Jannie, S. J., Geopolymers Structure, Processing, Properties and Industrial Applications, Woodhead Publishing, Cambridge, UK.

Rahier, H.; Simons, W.; Van Mele, B.; Biesemans, M., 1997. Low-temperature synthesized aluminosilicate glasses: Part III Influence of the composition of the silicate solution on production, structure and properties. Journal of Materials Science, 32(9), pp.2237-2247.

http://dx.doi.org/10.1023/A:1018563914630

Scrivenera, K. L.; Kirkpatrick, R. J., 2008. Innovation in use and research on cementitious material. Cement and Concrete Research, 38(2), pp. 128-136. http://dx.doi.org/10.1016/j.cemconres.2007.09.025

US Genological Survey: Mineral Commodity Summaries: Cement. Available at: http://minerals.usgs.gov/minerals/pubs/mcs/2013/mcs2013.p df

Yao, X.; Zhang, Z.; Zhu, H.; Chen, Y., 2009. Geopolymerization process of alkali-metakaolinite characterized by isothermal calorimetry. Thermochimica Acta, 493(1-2), pp. 49-54. http://dx.doi.org/10.1016/j.tca.2009.04.002

\section{Acknowledgements}

The research was carried out in the framework of the Project of the Latvian Council of Science: "Development of sustainable effective lightweight construction materials based on industrial waste and local resources" No. Z12.0412 